\title{
Regional Development Inequalities in Kenya: Can Devolution Succeed Where Other Strategies Failed?
}

\author{
Adoyo Laji \\ Department of Environmental Science, \\ Pwani University, \\ P.O Box 195-80108, \\ Kilifi, Kenya. \\ E-mail:lajiadoyo@gmail.com
}

Received: October 30, 2018

Accepted: February 12, 2019 Published: March 27, 2019

doi:10.5296/ijrd.v6i1.14547

URL: http://dx.doi.org/10.5296/ijrd.v6i1.14547

\begin{abstract}
Regional development planning strategies are often applied to reduce and in the long run eliminate major inequalities and disparities among regions. Since independence, the government of Kenya has employed numerous regional development planning strategies with the aim of addressing the worsening trend of spatial inequalities. These strategies include growth centre strategy, service centre strategy, District Focus for Rural Development and Rural Trade and Production Centres among others. Nonetheless, the effort of the government to create balanced regional development in all parts of the country has not borne any fruit. Instead, the country is still grappling with a dual spatial system characterized by polarized and unequal development in favour of those regions that had comparative advantage at independence. The introduction of the devolved system of governance, however, heralds the optimism that regional spatial inequalities would gradually be addressed. This paper explores the origin and dynamics of regional disparities and unbalanced development in Kenya and thereafter interrogates the potential of devolution in promoting balanced development of the various regions in the country. A desk study approach was used in undertaking this study. It was established that with devolution, there has been a marked increase in funds available for development in various regions of the country. As such, it offers the potential to redress the hitherto unbalanced regional development in Kenya.
\end{abstract}

Keywords: Regional Development, Regional Planning, Devolution, Dualism, Spatial inequalities 


\section{Introduction}

Regional development planning is a form of public planning that involves various categories of planning including economic, social, environmental and physical planning. A distinction is often made between regional development and regional planning. The former deals with the content of plans or programmes and usually denotes the form and level of change or improvement that takes place as a result of planning effort. The latter is more concerned with the procedures and practices by which the plan is implemented and the total impact it makes on the region (Ofori, 2002). In this regard therefore, regional development is more based on substantive theory and as such has captured the attention of governments more than procedural issues. This explains why in most countries in the world the purposes of regional planning usually contain strong economic overtones. Accordingly, a definite concept of development is always found to underlie regional planning (Friedmann \& Weaver, 1979).

The principle aim of regional development planning is a balanced development of the different parts of a country, and this is achieved by ensuring a balance between resource endowments, population distribution and the settlement structure. Such efforts are intended to reduce and in the long run to eliminate major inequalities and disparities among regions within a country (Friedmann \& Weaver, 1979). Even though the aims of regional development planning are nearly universal, some authors have pointed out that it is ridiculous to expect that regional disparities can be eliminated altogether. They argue that complete equality among regions is not possible even with the application of regional development planning. This, they point out, is because resources and human skills are unevenly distributed over different regions of a country and mobility of factors is imperfect (Hirschman, 1958). It is noteworthy that Hirschman and other proponents of polarization theory even advocated the creation of regional imbalances, in order to bring about economic development.

Since attaining political independence in 1963, Kenya has been grappling with the persistent problem of unbalanced regional development. Through various policies and interventions, the government has tried to reverse the discriminative effects of colonial policies that had created wide disparities and imbalances between regions. However, after decades of experimenting with different regional development strategies, the regional disparities and imbalances in economic, social and political development still persist (Friedrich-Ebert-Stiftung, 2012). These prevailing regional inequalities and imbalances have increasingly become a source of political and social conflict in the country. For instance, the $2007 / 08$ post-election violence was partly attributed to numerous cases of historical injustices emergent of marginalization of regions associated with the previous regimes. Addressing regional disparities in Kenya calls for a fresh approach which provides a framework for fostering more balanced development in the country. Such an approach hinges crucially on the formulation and implementation of equity oriented policies and programmes specifically targeted toward addressing regional disparities.

While highlighting their failure to achieve the desired objectives, this paper seeks to bring to light the plurality of regional development planning strategies that have been formulated and implemented in Kenya over the years. In addition, the paper proceeds to explore the potential 
of a devolved system of governance in addressing disparities in regional development in Kenya.

\section{Theoretical Framework}

This paper is informed by the following related theories. First, is the Growth Pole Theory which was postulated by Francois Perroux. By a growth pole, Perroux meant a regional center in abstract economic space from which centrifugal forces emanate and to which centripetal forces are attracted. The theory explains that growth does not occur everywhere and at the same time, but manifests itself at certain points or poles of growth with varying intensities. It further suggests that by concentrating investment and innovation in these 'poles of growth', development would either spontaneously or by inducement spread throughout the region (Perroux, 1955). The assumption made is that the selected regional growth poles would be able to transmit development impulses to the rest of the spatial system and thereby influence regional development.

The second theory which was largely influenced by the first one is Myrdal's "cumulative causation theory" (Myrdal, 1957). This theory attributes inequalities in regions as arising out of the initial disparities in access to development opportunities. These initial disparities work to cause circular and cumulative effects in the form of backwash (negative) and spread (positive) effects (Myrdal, 1957). With the cumulative process working in both directions, achievement of balanced regional growth and development is dependent on which of the preceding cumulative effects dominate.

Albert Hirschman (1958) in his book 'The Strategy of Economic Development' theorizes that the interregional inequality of growth is an inevitable concomitant and condition of growth itself. Thus in geographical sense, growth is necessarily unbalanced and this leads to what he referred to as 'polarization'. He argues that once growth takes a firm hold in one part of the national territory (region), it will set in motion certain forces that act on the remaining regions. In the end, the 'trickling down' effects would gain the upper hand over the 'polarization' effects (Hirschman, 1958). Even though both Myrdal and Hirschmann propagate the notion of polarized regional development, Hirschmann seems to take a more positive stance towards unbalanced growth and argues that ultimately a balanced regional development may be achieved.

The third theory is the central place theory postulated by Walter Christaller (1933). The cornerstone of Christaller's theory was the idea of a functional interdependence between a town and the surrounding region. The theory deals with the size, number, function and distribution of human settlements and it states that every place has a degree of importance, which is usually defined by its size of population or by its real size. Thus a central place, according to Christaller (1933), is a place which has central functions that extend over a large region in which other smaller central places exist. Hence, categories of central places performing varying functions and exerting influence on regions of various sizes can be envisaged.

Friedmann (1972) formulated a systematic and comprehensive center-hinterland development 
theory. He maintained that development occurs through a discontinuous, but cumulative process of innovation. It originates in a relatively small number of "centers of change". Innovations diffuse from these centers to areas of lower potential interaction. "Core regions" are major centers of innovative change, while all other territory consists of "peripheral regions" which are dependent on the core regions and whose development is largely determined by the institutions of the core regions.

It is imperative to note that nearly all the regional development planning strategies that have been formulated and implemented by the Kenya government have largely been based on either the growth pole theory or the central place theory. Myrdal's cumulative and causation theory and Hirschman's polarization and trickling down theory partly explain why such regional development planning efforts in Kenya have failed to bear fruit.

\section{Methodology}

In undertaking this study, a desk study approach was used. Thus, extensive literature review on the regional development planning regime in Kenya was done. Various documents were reviewed most of which provided valuable information on the subject of regional development planning in the country especially those focusing on policies and strategies employed to facilitate regional development planning. Government documents, publications from various authors as well as unpublished Postgraduate Theses formed the valuable sources of information for this study.

\section{Evolution of Regional Development Planning in Kenya}

\subsection{Pre-Independence Period}

Regional development planning in Kenya can be traced back to the mid-1940s when the British colonial government called upon the heads of Departments and Provincial Commissioners to prepare plans for post war recovery (Obudho, 1997). Nonetheless, it is argued that during this time, regional development planning was done on a more piecemeal basis and was primarily directed to addressing the needs of the white settlers (Maleche, 1998; Kosura, 2000). The colonial regional planning was characterized by alienation of high potential land found in the highlands for the exclusive settlement and commercial use by the European settlers. The indigenous Africans on the other hand were concentrated within 'African Native Reserves'. The result of this was a dichotomization of the country in respect of the African reserves and the European scheduled areas (Chweya, 1998). Nonetheless, the establishment of these European settlements (white highlands) and the African Reserves entailed a haphazard allocation of land without planning (Obudho, 1997).

Henceforth, development and investment in infrastructure facilities and other social services and amenities were concentrated in the "white highlands" region and the urban settlements which were mainly located in the same zone. The establishment of this nucleus economic region, which had great initial resource advantages, provided the core region around which the Kenyan model of evolving regions of economic and social disparities developed (Ominde, 1979). A centre-periphery relationship evolved, based primarily on the exploitation of spatial agricultural resources. This created the first major regional imbalances in development in the 
country (Maleche, 1998), with many areas that would have been developed neglected in favour of 'white highlands' and some urban areas (Obudho, 1998).

The regional disparity and dualism in Kenya that was nurtured by the colonial government policies culminated into fierce opposition to the government in the early $1950 \mathrm{~s}$ and subsequently, violence broke out. The colonial government responded by rolling out the Swynnerton Plan in 1954. This plan was primarily an agricultural policy plan (Maleche, 1998) aimed at imposing a pattern of integrated rural development and creating a politically stable, land owning peasant class more interested in economic gain than politics (Mackenzie \& Taylor, 1989). As such, the plan was essentially a politically motivated social experiment to pacify an increasingly restive indigenous population. Because of this, the plan was negatively received as just another oppressive policy of the European colonial authority. It therefore had limited impact in the light of its objectives (Maleche, 1998).

At the time Kenya attained political independence in 1963; the economy was characterized by distinctly unbalanced regional development. This was manifested in the form of existence of a distinct modern commercial and industrial sector versus the traditional farming sector. The upshot of this was the emergence of export enclave in the relatively high potential regions in the country and a subsistence periphery operated by a large number of peasantry in the marginalized areas (Syagga, 2006). This disparity was further exacerbated by emerging duality of the rural sector versus the urban sector. The colonial government policies therefore exacerbated rather than reduced spatial inequalities (Mackenzie \& Taylor, 1989).

\subsection{Regional Development Planning after Independence}

At independence in 1963, Kenya inherited a strongly centralized and vertically integrated regional development planning paradigm. This warped regional development planning policies of the colonial government promoted skewed development in different parts of the country (Chweya, 1998; Obudho, 1998). With a diverse ethnic composition occupying different regions in the country, a major task after independence was the building of national unity. Tribalism was seen as an evil and as a barrier to national progress. But more often than not, tribes and ethnic groups had clearly-defined territorial units. Because of this, decentralized planning on a regional or territorial base was seen by many as politically dangerous as it could foster disintegration (Mackenzie \& Taylor, 1989). Hence, the term regional development planning was rarely used, instead the terms rural or district planning was found more appropriate. These political constraints became serious impediments to effective regional development planning and the effects have become obvious in recent times.

After independence, the government of Kenya formulated various policies to promote national integration and at the same time address the inherited regional imbalances. The first major policy document was the constitution drawn out at independence which among other things, articulated policies to guide development at the national, regional and rural levels (GoK, 2007). Closely following on this, the government of Kenya came up with Sessional Paper No. 10 on "African Socialism and its Application to Planning in Kenya" which formed the main policy framework for development issues. This policy document served as Kenya's development bible for decades with one of its aim being removing the inequalities inherited 
from the colonial period (Friedrich-Ebert-Stiftung, 2012).

The Sessional Paper No. 10 of 1965 has however been criticized for failing to integrate regional development planning with the overall national development policy (Kosura, 2000). Instead, the policy provided a strategy that involved concentrating the small national investment capacity in the regions with the greatest absorptive capacity. It was only the surpluses that were to be directed to marginalized regions. The policy asserted that:

"To make the economy grow as fast as possible, development money should be invested where it will yield the largest increase in net output. This approach will clearly favour the development of areas having natural resources, good land and rainfall, transport and power facility" (GoK, 1965:46).

The Sessional paper thus had the effect of a skewed distribution of development expenditure in favour of those regions of the country that had already benefited from economic development owing to their inherent comparative advantage. Such regions included the former 'white highlands' and the urban areas. This regional development policy therefore unduly favoured Central Kenya and Nairobi. Coincidentally the dominant group in the ruling class during Kenya's independence hailed from these two regions.

In addition to the initial efforts to address regional imbalance, the Kenyan government prepared comprehensive five-year development plans addressing development needs of all sectors. These national development plans tended to reflect changes in policy focus and strategy as dictated by changing development circumstances and according to recommendations of the various policy papers, reports and commissions (GoK, 2007).

The first four year Development Plan of post-colonial Kenya (1966-1969) did not present any regional planning strategy different from the colonial development strategy of the fifties and early sixties. But it took cognizance to the fact that regional disparities existed and that there was need for a policy to ensure the distribution of economic growth among the people of various regions (Laji, 2009). The second Development Plan (1970-1974) contained the first formal commitment to development of rural areas. The key strategy of the plan was to direct an increasing share of resources available to the nation towards rural areas (Ikiara \& Okeyo, 1998). The principles and strategies of regional planning in Kenya were summed up as;

"concerned with the development which involves the use of land; promote the movement of people or goods, or modifies the physical environment. It deals with emerging patterns of production and residence, distribution throughout the country of the physical infrastructure of development; roads and railways, ......public buildings, houses, schools and hospitals". (GoK, 1970).

Despite its recognition of the need for a decentralized form of regional development planning, this second development plan failed to propose a programme of decentralization (Ikiara \& Okeyo, 1998).

The third Development Plan (1974-1978), like the second plan, gave emphasis to rural development. This plan was prepared at the time when the government had just adopted 
regional development strategies namely growth center strategy and service center strategy. Arising from this, a system of urban places believed to be critical in servicing the predominantly agricultural communities was identified in this plan (Ikiara \& Okeyo, 1998.

The fourth Development Plan (1979-1983) continued with the focus on rural development. The plan put emphasis on poverty reduction by creating gainful opportunities and provision of basic needs such as water, health care, education and housing for all. It conferred to the district development committees the responsibility of spatial distribution of government services by identifying in detail local resources and describing local projects which could promote agriculture, small scale industries and community development programmes (Ikiara \& Okeyo, 1998).

The fifth Development Plan (1984-1988) laid emphasis on promoting a better balance of development among the various regions in the country. The policy of growth centre as part of regional development planning was strengthened in this plan, with the spatial planning guidelines implicit in the designated service centre policy serving as the basic criteria for siting public sector investments. The District Focus for Rural Development (DFRD) strategy was further elaborated on in this Fifth Development Plan.

The theme contained in the fifth development plan was further reiterated in the Sessional paper No. 1 of 1986 on "Economic Management for Renewed Growth" (GoK, 1986). The primary aim of this policy document was to promote the development of an urban system that supported the growth of agriculture and the development of rural areas (GoK, 1986). This in turn would generate productive employment opportunities in non-farm activities.

The sixth Development Plan (1989-1993) represents perhaps the most comprehensive attempt to look at problems of the least developed regions (Obudho, 1997). The document points out that throughout the colonial period, the development of some regions was given low priority, a situation that persisted during the first three post-independence development plan periods. The plan thus focused on the promotion of rigorous growth of small urban centres so as to curb migration from rural areas to principal urban areas. The anticipated rapid expansion of small urban centres was also aimed at achieving greater integration between agriculture and other non-agricultural activities and especially the small-scale enterprises (Obudho, 1997).

The Seventh Development Plan (1994 - 1996) sheds light on the government's frustration with its regional development planning policies which were to be actualized using rural-urban balance strategy. The plan points out that even though the development of urban centres was still vital in achieving rural-urban balance, many urban centres had been unable to provide the necessary infrastructure and facilities. The plan acknowledges that owing to weak financial resources, the urban centres are unable to finance new infrastructural facilities or maintain existing ones (GoK, 1994).

\section{Regional Development Planning Strategies Applied in Kenya Since Independence}

Complementary to the National Development Plans and Sessional papers were regional development planning strategies which the government formulated from time to time to guide and shape regional development in the country. The strategies explicitly indicated the desired 
development goal of the government and the means of achieving that goal. Examples of these strategies include growth centre strategy; service centre strategy; Rural Trade and Production Centre strategy and District Focus for Rural Development Strategy.

\subsection{Growth Centre Strategy}

The policy to establish growth centres on a hierarchical basis was adopted as a regional development planning strategy in the 1970s (GoK, 2007). In developing these growth centers, the government identified potential for growth functions in a given urban centre with the aim of creating favourable opportunities for commercial and industrial development for the surrounding regions (Obudho, 1998). Arising from this, a few strategic regional urban centres were designated as principal towns to form centres of regional economic growth (GoK, 1978; GoK, 2007). These included Kisumu, Embu, Kakamega, Nakuru and Eldoret among others. These growth centers were given priority in the process of national economic investments in industrial, infrastructural, institutional and commercial development. In addition, the centers were to be linked to the regional resource hinterlands by a network of communication and transport systems.

The growth centre strategy as applied in Kenya was based on growth pole theory. Critics of this theory however, point out that the principles behind growth poles are rarely politically feasible without sufficient political will and even dictatorship. They argue that the strategy requires concentrated and sustained public investment at a very limited number of locations which may not be feasible if there is no political goodwill. Consequently, the growth pole policies have failed to initiate and nurture any tangible regional development (Polese, 1999). For example, in Kenya, lack of political will and apparent ethnicization of politics ensured that the government in office concentrated public investments in the home area of the president and totally ignored other designated growth centres in other regions. For instance, while Kisumu, Kakamega, Nakuru, Eldoret, Nyeri, Thika and Embu were designated as growth centers in 1969, it was only Thika and Eldoret that recorded reasonable growth during the presidency of Jomo Kenyatta and Daniel Moi respectively. Kisumu, Kakamega and Embu suffered lack of sufficient funding to raise them to the 'take off' stage (Otiso, 2005). As such, the centers failed to trickle down any benefits to the surrounding regions. This exacerbated the existing disparities amongst regions and brought forth the incessant clamour for a fair share of the national cake.

\subsection{Service Centre Strategy}

This regional development strategy consisted of the development of a planned network of designated service centres at different levels throughout the country to improve the quality of life in the rural areas and to stimulate integrated rural development $(\mathrm{GoK}, 1978)$. The aim of the strategy was to ensure an optimal use of infrastructure facilities and basic services. But these services were to be concentrated only in certain centres instead of dispersing them throughout the district (Obudho, 1998). It was expected that this would ensure that there was a more equitable and rational geographical distribution of infrastructural facilities and social services in terms of population distribution over the country (Obudho, ibid). 


\section{MInstitute Machink $_{\text {Inthe }}$}

The service centre strategy as domesticated in Kenya was based on central place theory. Critics of the central place theory however point out that it is static in conception. Furthermore, not all central places are capable of inducing economic and social development in the surrounding regions. Indeed critics observe that the designated central places oftentimes lack systematic effort to link their growth and expansion with plans for the development activities within the region where they are located. Hence, the creation of articulated hierarchies of urban centres in regions and rural areas does not in any way promote social and economic development of such areas (Misra et al, 1974 cited in Laji, 2009).

Both growth centre and service centre strategies were based on top-down approach which according to Obudho (1998), failed to trickle down due to the slow pace with which the designated urban centres developed. The trickle down approach which was to facilitate regional development was overtaken by backwash effects thereby aggravating the prevalent regional inequalities. By the middle of the 1970s, serious structural and operational difficulties were evident in both growth centre and service centre approaches in Kenya. It was clear that the expected trickle down effects and other manifestations of success of these centralized 'top-down' policies were not taking place (Kingoria, 1998). The disadvantaged areas continued to lag behind in development, hardly receiving investment resources and for most parts neglected.

Literature is replete with the reasons why growth center and service center strategies failed in Kenya. One of the key reasons for their failure is heavy reliance on anticipated investment by private developers in the designated centers. However, the location of investment and the type of business to engage in, is a decision made by developers who consider other factors such as the profit motive and not policy objective as envisaged by the government policies. According to Alila (2000) the growth centre and service strategies could therefore, not be effective in open market where individuals make personal choices. With such skewed investment options there would be increased socio-economic inequalities perhaps compounding the initial geographical disparities. The implication is that there are polarizing forces that are often stronger than spread mechanisms and these ultimately hinder the free dispersal of development (Alila, 2000).

\subsection{District Focus for Rural Development Strategy}

The apparent failure of growth centre and service centre approaches to transmit development impulses to surrounding regions compelled the government of Kenya to shift to a new strategy aptly named District Focus for Rural Development. Backed by the Office of the President, the then new approach was introduced as a major initiative in the process of decentralization planning and implementation of development in every district in Kenya (Kingoria, 1998). The strategy contained guidelines that outlined the procedures for shifting the responsibility for planning from the headquarters of ministries to districts. The districts were expected to help in identifying the projects that were to be given priority in each financial year (Kingoria, 1998). In other words, the strategy aimed at decentralizing development by making the district the centre of resource allocation. As such, the approach 
was to broaden the base of rural development decision making and also encourage local initiatives in order to improve methods of development problem identification, resource mobilization and project implementation.

Nonetheless, literature indicates that DFRD strategy was not without some inherent weaknesses that curtailed its implementation and reduced the anticipated development benefits within the regions. Chief among these was the fact that the process failed to consider the possibility of using the local government system, which relies on civic political process and closeness to the communities as an alternative structure (Kingoria, 1998). This non-inclusion of elected local authorities' leaders in regional development planning effectively stifled the transmission of development impulses through District Focus for Rural Development. Other critics of DFRD point out that the strategy was never devolution of authority to the regions, but rather was just another case of de-concentrated central control.

\subsection{Rural Trade and Production Centres Strategy}

The Rural Trade and Production Centre (RTPC) strategy was first adopted by the government of Kenya in the Sessional Paper No. 1 of 1986. An RTPC was meant to be "an existing town or village with a 1979 population below 5,000 inhabitants constituted either as an urban or simply as a trading centre under the jurisdiction of the county council" (GoK, 1986). The strategy was meant to concentrate resources in a number of urban centres by developing the urban infrastructure such that the aggregate impact of individual projects in rural areas would be maximized. Additionally, the strategy was to not only strengthen the performance and financing of Local Authorities in regional development but was also promote the informal sector development thereby generating off-farm employment opportunities in different regions (Ikiara \& Okeyo, 1998).

The selection of the RTPCs was based on the level of economic productivity, market size, infrastructure development, and levels of income and extent of local people's participation in the day to day economic activities of the area (Obudho, 1998). The RTPC programme was expected to run from 1986 to 2000 but was abruptly discontinued in 1992. Among the weaknesses of RTPC as a regional development strategy was its failure to align planning and implementation with functions of development and public administration at the district level. Moreover, the selection of RTPCs and the implementation of infrastructure projects and services programmes in these centres were carried out within the district framework and with the politicians wielding undue influence (Obudho, 1998). The short term interests of politicians thus militated against long term requirement of RTPC as a regional development planning strategy.

\subsection{Regional Development Authorities (RDA)}

The government of Kenya in its quest to promote regional development planning also used the natural resource criterion as a basis for demarcation of regions. These regions were delineated on the basis of physical, geographical and resource factors including river catchments and drainage basins rather than administrative, political or socio economic criteria. The main aim for the establishment of these RDAs was to rationalize equitable and balanced 
sustainable regional and national development in the country (GoK, 2007). Based on this, the following regions were delineated; Coast Development Authority, Tana and Athi River Development Authority, Ewaso Ngiro North Development Authority, Ewaso Ngiro South Development Authority, Lake Basin Development Authority and Kerio Valley Development Authority. These Regional Development Authorities were tasked with several functions, key among them include; to plan for the development of their areas and initiate project activities identified from such planning; and to develop long range development plans for their respective areas.

The government of Kenya undertakes the RDA approach as a strategy for regional development planning side by side with other regional development strategies. However, what has been evident over the years is lack of integration of these approaches to regional development planning. In fact, the strategies were implemented in isolation with no effort of creating synergy. Evidently, despite the establishment of RDAs in the 1970s, there is little, if any, development within the concerned regions that can be attributed to the authorities. Instead, lack of clarity on their mandates has made RDAs to suffer from operational overlaps and conflicts with national, sectoral and other statutory institutions and development agencies at all levels. Either because of or in addition to this, RDAs have lost their strategic focus and have become largely ineffective in fostering regional development (GoK, 2007).

\subsection{Decentralizing Funds for Regional Development}

After numerous attempts by the government to address the imbalance in regional development planning failed to bear fruit, the government of Kenya in the 1990s embarked on introducing devolved (geographically earmarked) funds (Friedrich-Ebert-Stiftung, 2012). The process entailed the transfer of national funds to Local Authorities or to Constituency CDF Committees that were supposed to use the funds to initiate development projects and programmes within their areas of jurisdiction. With such initiatives, the central government hoped to facilitate development within various regions in the country. The most notable of these funds were the Local Authority Transfer Fund (LATF) created through the LATF Act number 8 of 1998; the Road Maintenance Levy Fund (RMLF) created through the Kenya Roads Act, 2007; the Rural Electrification Fund created through the Energy Act of 2006 and the Constituency Development Fund (CDF) created through the CDF Act of 2003 (Friedrich-Ebert-Stiftung, 2012).

Despite these piecemeal legislative efforts toward financial decentralization targeted at addressing inequality in regional development, stark regional disparity still persists in Kenya (Friedrich-Ebert-Stiftung, 2012; KNBS, 2013). For instance, there are wide disparities in access to road infrastructure in various regions. While there is a high road density in Thika with a density ratio of 1.12 , other regions such as Tana River and Turkana have very low density ratios of 0.02 and 0.04 respectively (SID, 2004). Similarly, there are wide disparities in access to electricity with more than $20 \%$ of households within central region having access as compared to only $1.6 \%$ in Western region (KNBS, 2013). Access to water by households in different regions also varies. While majority of the residents of Kiambu region have access to water, more than $80 \%$ of residents of Narok region do not have access to improved source 
of water (KNBS, 2013).

\subsection{Failure of the Regional Development Planning Strategies to Address Inequalities}

It is evident from the foregoing discourse that despite the efforts of the government aimed at achieving equitable and balanced regional development through formulation of the various policies and strategies, as well as initiating plurality of financial decentralization strategies, glaring regional disparities still persist. Such egregious imbalance, has over the years been exacerbated imprudent allocation of public finances without any criterion. Consequently, many government funded regional development projects tend to go to regions represented by powerful politicians, leaving other regions quite marginalized (SID, 2004). Such regional disparities manifest themselves through economic indicators such as human settlement patterns, industrial development patterns, per capita income, infrastructure, and unemployment levels as well as social indicators such as access to public amenities like piped water, electricity, illiteracy rates, number of hospital beds and doctors among others. Owing to the failure of the previous efforts, an alternative regional development planning strategy ought to be considered.

\section{Is devolution a panacea to regional inequalities?}

Kenya promulgated a new constitution in 2010 (RoK, 2010). The major driving force behind the search for a new constitution was the perception that there are widespread regional disparities in the country. In order to address this long-standing national problem, devolution of power and governance to the regions was enshrined in the constitution (RoK, 2010). Devolution is generally defined as a process of transfer of political, administrative and fiscal management powers between central government and lower levels of government, primarily operating at regional levels (IEA, 2010). The resultant structure is that of a state with a variety of regional levels of government. Kenya's Constitution establishes forty seven county governments based on administrative boundaries of what used to be districts by 1992 . These County governments came into being after the general elections that were held in March 2013. The established county governments are responsible for a range of service delivery functions that work toward promoting development within such regions. The constitution goes further and specifies the roles of each level of government, including the rules governing fiscal arrangements. Explicitly, the national government is obliged to ensure that its public finance expenditure "shall promote the equitable development of the country, including special provisions for marginalized regions" (RoK, 2010).

The advent of the devolved government has been hailed by a number of Kenyans and other proponents who view it as a solution to the hitherto unbalanced regional development. The perceived promise of equitable distribution of national resources brought about by this new dispensation is expected to address regional inequalities that have characterized Kenya's regional development planning agenda for many decades (Friedrich-Ebert-Stiftung, 2012). With the authority to make public policy decisions in the political, administrative and fiscal spheres conferred on the counties by the supreme law of the land, proponents of devolution argue that such turn of events would improve efficiency of resource allocation thereby having a strong impact on the ability of the national government to fulfil its duties of promoting 
regional development and controlling parasitic activities. Achievement of regional development is made possible since the devolved sub-national units are closer to the people than the national government and are therefore better placed to respond to the diverse regional needs (Friedrich-Ebert-Stiftung, 2012).

The Constitution establishes the Commission on Revenue Allocation (CRA) which has been dubbed the heartbeat of devolution. CRA decides what amount of money each county gets every year. It is responsible for vertical and horizontal sharing of resources. The decentralization of resources from the center has taken two forms (CRA, 2012). The first is the equitable share of the revenue raised nationally in each financial year. It is stipulated that not less than 15 per cent of this revenue is shared equitably among the regions on the basis of a pre-determined formula. The formula that was developed by the CRA and approved by the national assembly took into account regional disparities among counties and the need to remedy them. Arising out of this, the revenues are allocated to the county governments based on the weighting as shown on the table 1 .

Table 1. Revenue sharing among counties in Kenya

\section{Parameter Percentage weights}

Population

Basic equal share

Poverty index

Land area

Fiscal responsibility

Source: CRA (2012).

The allocation formula implies that counties or regions receive a greater share of revenue if they have a larger population, higher poverty rate and a larger land mass. Thus, the level of development in each county is factored in the allocation of revenue and as such, counties that are considered less developed will get a proportionally higher amount than those that are more endowed with resources (CRA, 2012). Because all counties face some fixed costs of running their government, 25 per cent of the revenues are shared equally among all counties. Another 2 percent of revenue is provided as an incentive for fiscal responsibility. The idea is that those counties that manage their resources better and are more effective in mobilizing their own resources are rewarded by receiving a higher share of the resources under the fiscal responsibility parameter (CRA, 2012). This direct allocation of public funds among and between regions through the budget is the main tool that devolution as a strategy uses to address regional inequalities that has beset the regional development planning paradigm in Kenya. 


\section{Macrothink}

International Journal of Regional Development

ISSN 2373-9851

2019, Vol. 6, No. 1

The second form of decentralization of resources is through the equalization funds. This is part of the revenue framework established by the constitution to address service level gaps in marginalized regions of Kenya, in order to bring them up to par with the rest of the country (CRA, 2012). The CRA is mandated to determine, publish and regularly review a policy which guides the identification of marginalized regions to benefit from equalization funds. These equalization funds see at least 0.5 per cent of Kenya's annual revenue distributed to the poorer or least developed regions of the country for a period of 20 years to assist in the provision of basic services (water, roads, health services) so as to bring the quality of services to the level generally enjoyed by the developed regions in the country (CRA, 2012). This is meant to ensure that the not-so-developed regions are able to catch up with the relatively developed counterparts.

The annual reports by the Controller of Budget indicate that the amount of funds available for countries to use has markedly increased over the five years of implementation of devolution (RoK, 2014; 2015; 2016; 2017). For instance, the total revenue available to the counties for the financial year 2013/2014 amounted to Kshs. 224 billion. This increased to Kshs. 304.78 billion in 2014/2015 FY; then to Kshs. 343.18 billion in 2015/2016 FY and to Kshs. 369.45 billion in 2016/2017 financial year. Similarly, the funds spent by the county governments on development activities have been on an upward trend for the last five years. For example, in 2013/2014 FY, the county governments spent a total of Kshs. 36.6 billion on development activities. This rose to Kshs. 90.44 billion in 2014/2015; then to Kshs. 103.45 billion in 2015/2016 FY and then to Kshs. 103.34 billion in 2016/2017 financial year. Table 2 gives a summary of the total funds available to the counties and the amount spent on development activities.

Table 2. Funds disbursed to various regions (counties)

$\begin{array}{lll}\text { Financial Year (FY) } & \begin{array}{l}\text { Total Funds available } \\ \text { Counties (billion Kshs.) }\end{array} & \begin{array}{l}\text { Amount spent on Development } \\ \text { activities (billion Kshs.) }\end{array} \\ 2013 / 2014 & 224 & 36.6 \\ 2014 / 2015 & 304.78 & 90.44 \\ 2015 / 2016 & 343.18 & 103.45 \\ 2016 / 2017 & 369.45 & 103.34\end{array}$

Source: RoK (2014; 2015; 2016; 2017).

With the funds available to counties continuing on an upward trend, there have been notable infrastructural and human resource developments. In particular, a number of counties have constructed several Early Childhood Development and Education (ECDE) centers and Polytechnics (Savage \& Lumbasi, 2016) In addition, healthcare delivery has improved with virtually all counties registering improvement in pre and post-natal visits, immunization of 
children, child nutritional status, life expectancy and reduction in maternal and child mortality (Mugo, et al, 2018). Evidently, devolution has led to improvement in quality of infrastructure and service delivery in a number of previously marginalized regions. This demonstrates that as a regional development strategy, devolution offers the potential to redress the hitherto unbalanced regional development in Kenya.

\section{Conclusion}

Kenya has grappled with the problem of unbalanced regional development. The formulation and application of different regional development planning strategies over the years, has failed to address the problem. This has mainly been attributed to the fact that in Kenya's centralized system; policy makers took decisions that reflected the interests of the entire country. But this became inefficient especially in cases where those interests differed between regions, meaning that some regions ended up not benefitting from the national policy. A more decentralized form of governance makes eminent sense, given this Kenya's past experience with the regional development planning strategies. Accordingly, devolution is seen as a way to enhance the efficiency of service provision, by allowing a closer match between public policies and the needs of the different regions. Evidently, there is a lot of potential in devolution spurring regional development in various parts of the country. Indeed, there are clear pointers that the lagging regions have started moving toward the take-off stage albeit in small steps.

\section{References}

Alila, P. O. (2000). Rural Development in a Regional Planning Context: The Kenya Experience. In P. O. Alila and Kosura, W. O. (Eds.), Regional Development Policy and Practices in Africa and Asia: A Comparative Study. Nairobi, UNCRD.

Christaller, W. (1933) Central Places in Southern Germany. Trans. C. Baskin, New Jersey, Prentice Hall.

Chweya, L. (1998). Regional Development in Kenya: An Assessment of Performance. In A. Tirfie, P. Ngau and Mwangi, I.K. (Eds.), Regional Development Policy in Africa: Problems and Prospects Toward the $21^{\text {st }}$ Century. Nairobi, UNCRD.

Commission on Revenue Allocation (CRA). (2012). Recommendations on Sharing of Revenue Raised Nationally between the National and County Governments for the Fiscal Year 2012/2013, Nairobi, CRA. Retrieved from https://www.crakenya.org/wp-content/uploads/2013/10/

Friedmann, J., \& Weaver, C. (1979) Territory and Function: The Evolution of Regional Planning. London, Edward Arnold.

Friedmann, J. (1972). A General Theory of Polarized Development. In N. Hansen (Ed.), Growth Centres in Regional Economic Development. New York, The Free Press.

Friedrich-Ebert-Stiftung. (2012). Regional Disparities and Marginalization in Kenya, Nairobi, Friedrich-Ebert-Stiftung.

Retrieved

from 
https://library.fes.de/pdf-files/bueros/kenia/09859.pdf

Hirschman, A. O. (1958). The Strategy for Economic Development. New Haven, Yale University Press.

Ikiara, G. K., \& Okeyo, Z. A. (1998). Kenya's Experience with Economic Policies for Regional Development. In A. Tirfie, P. Ngau and Mwangi, I.K. (Eds.), Regional Development Policy in Africa: Problems and Prospects Toward the $21^{\text {st }}$ Century. Nairobi, UNCRD.

IEA (Institute of Economic Affairs). (2010). Devolution in Kenya: Prospects, Challenges and the Future. Nairobi, IEA. Retrieved from https://www.ieakenya.or.ke/downloads.php?page=Devolution-in-Kenya.pdf

Kenya, Government of (1979) Development Plan: For the Period 1979 to 1983. Nairobi, Government Printer.

Kenya, Government of (1989) Development Plan 1989 - 1993, Nairobi, Government Printer.

Kenya, Government of (1978) Human Settlements in Kenya: A Strategy for Rural and Urban Development, Nairobi, Ministry of Lands and Settlement.

Kenya, Government of (2007) Regional Development Policy, Nairobi, Ministry of Regional Development Authorities.

Kenya, Government of (1986) Sessional Paper No. 1 of 1986, Economic Management for Renewed Growth, Nairobi, Government Printer.

Kenya, Republic of (2010) The Constitution of Kenya, Nairobi, Government Printer.

extwprlegs1.fao.org/docs/pdf/ken127322.pdf

Kenya, Republic of (2014) County Government: Annual Budget Implementation Review Report, Financial Year 2013/2014, Nairobi, Office of the Controller of Budget.

Kenya, Republic of (2015) County Government: Annual Budget Implementation Review Report, Financial Year 2014/2015, Nairobi, Office of the Controller of Budget.

Kenya, Republic of (2016) County Government: Annual Budget Implementation Review Report, Financial Year 2015/2016, Nairobi, Office of the Controller of Budget.

Kenya, Republic of (2017) County Government: Annual Budget Implementation Review Report, Financial Year 2016/2017, Nairobi, Office of the Controller of Budget.

Kenya National Bureau of Statistics (KNBS). (2013). Exploring Kenya's Inequality: Pulling Apart or Pooling Together? Nairobi, KNBS and SID. Retrieved from https://www.knbs.or.ke/download/exploring-kenya-inequality-national-report/

Kingoria, G. K. (1998) "Research for Regional Development", in S.O. Akatch (ed) (1998) Sub-National Planning in Kenya, Nairobi, Centre for Urban Research. (Pgs. 10-18). 
Kosura, W. O. (2000). Urban and Regional Development Planning in Kenya. In P. O. Alila and Kosura, W. O. (Eds.), Regional Development Policy and Practices in Africa and Asia: A Comparative Study, Nairobi, UNCRD.

Laji, A. D. (2009). The Planning Challenges of Awasi Urban Centre in Nyando District, Kenya. Unpublished M.A. (Planning) Thesis, Department of Urban and Regional Planning, University of Nairobi.

Mackenzie, F., \& Taylor, D. R. F. (1989). Inequality in Murang'a District, Kenya; Local Organization for change. In K. Swindell, J.M. Baba and Mortimore, M.J. (Eds.), Inequality and Development: Case Studies from the Third World, London, Macmillan Publishers.

Maleche, Z. (1998). Kenya's Experience with Regional Development Policies", in A. Tirfie, P. Ngau and Mwangi, I. K. (Eds.), Regional Development Policy in Africa: Problems and Prospects Toward the $21^{\text {st }}$ Century. Nairobi, UNCRD.

Mugo, P., Onsomu, E., Munga, B., Nafula, N., Mbithi, J., \& Owino, E. (2018). An Assessment of Healthcare Delivery in Kenya under the Devolved System, KIPPRA Special Paper, No. 19.

Myrdal, G. (1957) Economic Theory and Underdeveloped Regions. Stockholm, Harper and Row.

Obudho, R. A. (1997). Development of Least Developed Regions and Border Areas in Kenya: Problems and Prospects. In W. Gooneratne and Obudho, R.A (Eds.), Contemporary Issues in Regional Development Policy: Perspectives from Eastern and Southern Africa, Aldershot, Averbury.

Obudho, R. A. (1998). District Focus for Rural Development Strategy: A Bottom Up Appraisal to Spatial Planning. In S.O. Akatch (Ed.), Sub-National Planning in Kenya, Nairobi, Centre for Urban Research.

Obudho, R. A., \& Taylor, D. R. F. (1979). The Spatial Structure of Development: A Study of Kenya. Colorado, West View Press.

Ofori, S. C. (2002). Regional Policy and Regional Planning in Ghana: Making things happen in the Territorial Community. England, Ashgate Publishing Company.

Ominde, S. H. (1979). Regional Disparities and Employment Problem in Kenya. In R.A. Obudho and Taylor D.R.F. (Eds.), The Spatial Structure of Development: A Study of Kenya. Colorado, West View Press.

Perroux, F. (1955). Note Sur la Notion de Pole de Croissance. In I. Livingstone (Ed.), Development Economics and Policy: Selected Readings. London, Allen and Unwin.

Polese, M. (1999). From Regional Development to Local Development: On the Life, Death and Rebirth of Regional Science as a Policy Relevant Science. Canadian Journal of Regional Science, XXII(3), 299-314. 


\section{Macrothink}

International Journal of Regional Development

ISSN 2373-9851 2019, Vol. 6, No. 1

Savage, A., \& Lumbasi, L. (2016). The Impact of Decentralization in Kenya, A Masters in Development Practice Paper submitted to the University of Dublin.

Society for the International Development (SID). (2004). Pulling Apart: Facts and Figures on Inequality in Kenya, Nairobi, SID. Retrieved from https://www.sidint.net/sites/www.sidint.net/files/docs/pulling-apart.pdf

Syagga, P. M. (2006). Land ownership and use in Kenya: Policy Prescriptions from Inequality Perspective. In Society for International Development (SID), Readings on Inequality in Kenya: Sectoral Dynamics and Perspectives. Nairobi, SID.

\section{Copyright Disclaimer}

Copyright for this article is retained by the author(s), with first publication rights granted to the journal.

This is an open-access article distributed under the terms and conditions of the Creative Commons Attribution license (http://creativecommons.org/licenses/by/3.0/). 